\title{
Hallittua persoonallisuutta Ääni-ihanne ja äänenmuodostus saksofoninsoiton eri tyylien opetuksessa
}

Musiikinlajien välisten erojen problematiikka on pitkään ollut yksi musiikintutkijoiden lempiaiheista. Toisinaan vertailevaa tutkimusta on tehty jyrkän arvottavalla asenteella tarkoituksena todistaa jonkun musiikinlajin paremmuus toiseen nähden. Tutkimusta on tehty myös vähemmän arvottavista lähtökohdista. Tällöin on pyritty lähestymään eri tyylejä niiden omat erityispiirteet ja käsitystavat huomioon ottaen. Tällainen tutkimusasenne kunnioittaa kohdettaan paremmin. Esimerkiksi rocklaulajan osaamisesta ja musiikillisista tavoitteista saadaan todennäköisesti puutteellinen kuva, jos laulutekniikkaa tai lauluääneen liittyviä ihanteita arvioidaan pelkkien klassisen laulunopetuksen käsitysten perusteella. Tutkija tarvitsee rockin estetiikan ja koko populaarikulttuurin ymmärtämystä.

Suomalaisessa musiikkikoulutuksessa opettajat ja oppilaat ovat usein tekemisissä klassisen musiikin, jazzin, populaarimusiikin ja kansanmusiikin erojen ja yhtäläisyyksien kanssa. Itse olen vertaillut klassista musiikkikoulutusta ja jazzopetusta yhden erityisalueen - saksofoniopetuksen - näkökulmasta. Saksofoni on sointinsa puolesta hyvin monivivahteinen instrumentti ja monet erot saksofonityylien välillä ovatkin puhaltimien soittoon perehtyneelle tutkijalle helposti havaittavissa.

Esitykseni perustuu keväällä 2002 tarkastettuun pro gradu -tutkielmaani ”Lämmin ja pyöreä" - Tutkimus saksofoninsoiton äänenlaadun ihanteista ja äänenmuodostuksesta suomalaisessa saksofoninsoitonopetuksessa, jota varten haastattelin vuoden 2001 aikana yhteensä kuutta Helsingissä vaikuttavaa saksofoninsoitonopettajaa. Heistä kolme - Juhani Aaltonen, Kari Heinilä ja Pekka Pylkkänen - toimii jazzmusiikin ja jazzin sukuisen musiikin, ennen kaikkea improvisointia keskeisenä elementtinään korostavan musiikin alueella. Toiset kolme - Pekka Savijoki, Olli-Pekka Tuomisalo ja Juha Keikkonen - opettavat klassista eli niin sanottua taidemusiikin saksofoninsoittoa. Tärkeimpiä lähteitäni ovat siis näiden opettajien haastattelut. Haastatellut opettajat ovat enimmäkseen keskittyneet opettamaan jo pidemmälle ehtineitä saksofonisteja, 
mutta ainakin Tuomisalolla, Keikkosella ja Pylkkäsellä on kokemusta myös vähemmän aikaa soittaneiden opettamisesta.

Soitan itse saksofonia, klarinettia ja huilua, ja tietämykseni saksofonin ja muiden puupuhaltimien soitosta ja soitonopetuksesta perustuu siis osittain omille kokemuksilleni. Näkökulmani onkin käytännöniäheinen. Keskityn tarkastelemaan saksofoniopetuksen taustalla vaikuttavia soittimen ääneen liittyviä ihanteita ja käsityksiä, ääniihanteiden teknistä toteutusta sekä sitä, miten käsitykset näkyvät käytetyissä opetusmenetelmissä.

\section{Haastateltavat}

Juhani Aaltonen on syntynyt vuonna 1935 Kouvolassa. Hän on asunut vuodesta 1969 Vantaalla ja opettanut saksofoninsoittoa mm. Oulunkylän Pop \& Jazz Konservatoriossa ja Sibelius-Akatemian jazzlinjalla. Aaltosella ei ole saksofoninsoitonopettajan koulutusta, joten hänellä ei myöskään ole koskaan ollut opettajan virkaa tai tointa. Nykyisin hän opettaa saksofoninsoittoa lähinnä yksityisesti. Saksofonistina ja huilistina Aaltonen on maamme eturivin jazzmuusikoita ja työskennellyt ulkomailla $\mathrm{mm}$. Euroopassa ja Yhdysvalloissa. Aaltonen on ollut perustamassa Helsinkiin jazzin ammattilaisista koostuvaa Uuden musiikin orkesteri UMO:a, esiintynyt ja levyttänyt Edward Vesalan, Otto Donnerin ja Heikki Sarmannon yhtyeissä ja myös omalla nimellään (mm. Etiquette 1974, Springbird 1979, Prana - Live at Groovy 1981 ja Déjà $V u$ 2000). Aaltosen itsensä mukaan hänen taiteilijantyönsä kannalta ratkaiseva merkitys on ollut hänen 1980-luvulla kokemallaan hengellisellä herätyksellä. Hän onkin julkaissut musiikkia, jolla on hengellinen teema (esim. I Love You Lord 1991 ja O lord, You're beautiful 1993). Aaltosen työ ei ole rajoittunut jazziin ja hengelliseen musiikkiin vaan hän on studio- ja keikkamuusikkona tottunut soittamaan hyvin paljon myös tanssi- ja viihdemusiikkia. Onpa hän soittanut muutaman vuoden myös maamme rockin legendoihin kuuluvan Tasavallan presidentti -yhtyeen riveissä.

Pekka Pylkkänen on syntynyt vuonna 1964 Helsingissä, missä hän edelleen asuu. Hän työskentelee Helsingin ammattikorkeakoulu Stadian pop/jazzmusiikin koulutusohjelman puhaltimien lehtorina ja yliopettajana. Pylkkänen on aktiivinen jazzmuusikko ja opiskellut saksofoninsoittoa Sibelius-Akatemian lisäksi myös Hollannissa. Hän on soittanut UMO:ssa useaan otteeseen vuodesta 1994 lähtien ja hänen johtamansa Putkipaja- eli Tube Factory -yhtyeensä on julkaissut kaksi levyä Naxos-levymerkillä (Pekka's Tube Factory 1999 ja Opaque 2001). Ulkomaan esiintymisten huippuhetkistä Pylkkänen itse mainitsee konsertin Pekingin musiikkifestivaaleilla. Pylkkänen soittaa erilaisten saksofonien lisäksi myös mm. huilua ja bassoklarinettia.

Kari "Sonny" Heinilä on syntynyt Kiukaisissa vuonna 1966. Hän on asunut Espoossa vuodesta 1984. Hän työskentelee Sibelius-Akatemiassa jazzmusiikin lehtori- 
na, ja myös hän on soittanut UMO:ssa vuosina 1987-1994. Heinilä tunnetaan etenkin tenori- ja sopraanosaksofonistina, mutta hän soittaa myös huilua. Heinilä mainitsee harrastuksenaan perehtyneensä arabialaisturkkilaiseen musiikkiin ja soittimiin. Hänen ensimmäinen omalla nimellään julkaisemansa levy Tribus ilmestyi vuonna 1999.

Pekka Savijoki on syntynyt vuonna 1952 Helsingissä, ja asuu edelleen siellä. Hän on opiskellut klassista saksofoninsoittoa ensin Sibelius-Akatemiassa Eero Linnalan johdolla ja sen jälkeen ensimmäisenä suomalaisena saksofonistina Pariisin konservatoriossa Daniel Deffayet'n oppilaana. Savijoki on Sibelius-Akatemian saksofoniluokan lehtori ja käytännössä kaikki maamme konservatoriotason klassisen saksofonin soitonopettajat ovat olleet hänen oppilainaan. Cambridgen yliopiston julkaisuihin kuuluvan kirjan The Cambridge companion to the saxophone klassisia saksofonisteja esittelevässä luvussa "Influential soloists" (Dryer-Beers 1998) Savijoki on ainoa mainittu suomalainen saksofonisti. Hän onkin esiintynyt solistina paljon myös ulkomailla ja levyttänyt monia tärkeitä saksofoniteoksia. Savijoki on tilannut ja esittänyt suomalaisilta säveltäjiltä kuten Esa-Pekka Saloselta ja Paavo Heiniseltä konserttoja, sooloteoksia ja kamarimusiikkia. Savijoki soittaa kamarimusiikkia Suomalaisessa saksofonikvartetissa, jonka muita jäseniä ovat Juha Keikkonen, Kai Ruskeepää ja Timo Rantanen.

Juha Keikkonen on vuonna 1970 Lieksassa syntynyt klassinen saksofonisti. Hän muutti vuonna 1989 Helsinkiin opiskellakseen Sibelius-Akatemiassa Pekka Savijoen saksofoniluokalla, jolta hän valmistui vuonna 1996. Vuodesta 1993 hän on työskennellyt saksofoninsoitonopettajana Helsingin konservatoriossa, josta hänelle vuonna 2001 myönnettiin saksofoninsoiton lehtorin virka. Hän on opettanut myös Hyvinkään musiikkiopistossa ja Keski-Helsingin ja Länsi-Helsingin musiikkiopistoissa. Keikkonen on kokenut orkesterimuusikko ja esiintynyt mm. Radion sinfoniaorkesterin, Suomen Kansallisoopperan orkesterin, Tampereen, Lahden, Turun ja Helsingin kaupunginorkesterien ja Avanti!:n riveissä. Osassa näistä orkestereista hän on toiminut muusikkona myös levytyksissä. Lisäksi hän on Suomalaisen saksofonikvartetin jäsen.

Olli-Pekka Tuomisalo on syntynyt vuonna 1970 Helsingissä, missä hän edelleen myös asuu. Hän opettaa saksofoninsoittoa Musiikkiopisto Juvenaliassa ja Riihimäen musiikkiopistossa. Hän on niin ikään Savijoen oppilas ja valmistui Sibelius-Akatemiasta vuonna 1999. Tuomisalo on julkaissut kolme levyä (Elokuisessa Helsingissä 1997, Syysrunoelma 1999 ja Kevättuulahdus 2001), joilla hän on esitellyt suomalaista saksofonirepertuaaria mukaan lukien monia täysin unohdettuja teoksia. Tuomisalo on esiintynyt parikymmentä kertaa eri orkesterien solistina Suomessa ja toiminut myös orkesterimuusikkona.

Olisi aliarviointia kutsua Aaltosta, Heinilää ja Pylkkästä jazzmuusikoiksi ja jazzpedagogeiksi, jos jazzilla tarkoitetaan vain tiettyä historiallista musiikin lajia, joka eroaa selkeästi esimerkiksi muusta populaarimusiikista. Haluan tässä yhteydessä kui- 
tenkin ymmärtää jazzin laajemmin niin, että se tarkoittaa afroamerikkalaista ja afroamerikkalaisvaikutteista eurooppalaista musiikkia, jossa usein improvisointi on keskeisessä osassa. Juuri suhde improvisointiin ja afroamerikkalaiseen musiikkiin pohjautuva musiikin estetiikka erottavat nämä haastateltavat omaksi ryhmäkseen tutkimukseni haastateltujen joukosta. Käsittelen myös klassiseen musiikkiin erikoistuneiden saksofoninsoitonopettajien haastatteluista saatua tietoa. Näiden pedagogien näkemykset pohjautuvat klassiseen ranskalaiseen saksofonitraditioon.

\section{Saksofoni soittimena}

Belgialainen Adolphe Sax patentoi saksofonin Pariisissa vuonna 1846. Se otettiin pian käyttöön sotilassoittokunnissa, joissa se toi ratkaisun balanssiongelmaan vaski- ja puupuhaltimien välillä voimakkaan ja läpitunkevan äänensä ansiosta. Saxin instrumenteista kehitettiin kokonainen saksofoniperhe, johon kuuluvat korkeimmasta instrumentista matalimpaan es-(vireinen) sopranino-, b-sopraano-, es-altto-, b-tenori-, es-baritoni- ja b- bassosaksofoni. Käytännössä kaikkien saksofonien perusääniala ulottuu kirjoitettuna pienen oktaavialan b:stä kolmannen oktaavialan f:ään. Monet soittajat pystyvät kuitenkin soittamaan jopa neliviivaiseen f:ään asti. Näillä instrumenteilla on kullakin oma leimallinen sointivärinsä. Saksofoni on ollut tärkeä instrumentti jazzissa, johon se on kulkeutunut amerikkalaisten sotilassoittokuntien kautta, ja yhä useammat taidesäveltäjätkin ovat käyttäneet soitinta teoksissaan. (Baines 1991: 142146.)

Kuten klarinetti saksofoni on puupuhallin - vaikkakin tehty ohuesta metallista, yleensä messingistä, tai joskus muovista. Saksofonin putki on kartionmuotoinen ja sen poraus on melko laaja (Baines 1991: 142). Soittimen ääni saa alkunsa suukappaleeseen kiinnitetyssä yksinkertaisessa ruokolehdykässä eli lehdessä tai kielessä, joka saatetaan värähtelemään puhaltamalla. Edelleen soittimen sisälle muodostuu värähtelevä ilmapatsas. Ensisijaisena värähtelijänä toimiikin nimenomaan ilma (Hornbostel \& Sachs 1974: 43). Toimintaperiaatteensa mukaan saksofoni voidaan luokitella Hornbostelin ja Sachsin (1974: 43-49) soitinten luokitusjärjestelmässä kuulumaan aerofoneihin ja klarinettien alaryhmään.

Saksofonissa ilmapatsaan pituutta säädellään sormituksilla. Toisin sanoen soittaja avaa tai sulkee sormillaan soittimen rungossa kiinni olevia läppiä, jotka suljettuina peittävät ns. ääniaukkoja. Suukappaleen ja lehden valinta vaikuttavat jo osaltaan merkittävästi musiikilliseen lopputulokseen (ks. esim. Tiel 1963: 17-29, Liebman 1994: 31-36). Kun välineet on valittu, soittaja voi vaikuttaa soittimen äänen korkeuteen, voimakkuuteen ja laatuun muun muassa hengitystekniikallaan käyttämällä pallean seudun lihaksia, kurkunpään ja äänihuulten asentoa muuttamalla, huuliotteellaan eli ansatsillaan, soittoasennollaan, kielen asentoa ja suun muotoa muuttamalla, erilaisia 
artikulaatiotapoja käyttämällä, kasvojen lihaksia aktivoimalla ja leuan asentoa muuttamalla. (Mm. Horch 1998, Liebman 1994.)

Soittotekniikat eri saksofoneilla ovat periaatteessa samanlaiset: erot löytyvät tehtävien liikkeiden suuruudesta ja niiden suhteesta ilman käyttöön puhalluksessa. Esimerkiksi sopraanosaksofonin intonaation eli sävelpuhtauden kontrollin muuttamiseksi vaaditaan pienempi liike kurkussa ja/tai alahuulessa kuin baritonisaksofonin kohdalla. Soitinten erilainen koko ja muoto vaikuttavat soittoasentoon. (Liebman 1994: 5; Turner 1998.)

Saksofoni on ainutlaatuinen soitin laajan sointivärivalikoimansa ansiosta. Yksi syy tähän lienee soittimen rikas yläsävelsarja. Soittajan on mahdollista erilaisilla teknisillä muutoksilla muuttaa sointia huomattavasti. Tätä onkin käytetty hyväksi muun muassa nykymusiikissa (ks. Delangle ja Michat 1998: 174-180). Jazzissa ihanteena pidetään persoonallista ääntä ja mahdollisuutta käyttää eri sointivärejä vapaasti ilmaisullisina keinoina (Ingham 1998). Perussoinnin muuttamisen lisäksi saksofonisti voi vaikuttaa musiikilliseen lopputulokseen myös artikulaatiotavoillaan ja vibraton käytöllään. Lisäksi soitosta saatava vaikutelma riippuu mm. fraseerauksesta, liukujen, slurrien eli sidekaarien, korukuvioiden ja trillien sekä ns. "väärien sormitusten" käytöstä yms. (ks. esim. Liebman 1994: 37-40; Roach 1998: 92-93).

Saksofonin artikulaatio tapahtuu yleensä kielittämällä: ilman kulku suukappaleeseen katkaistaan koskettamalla lehdykkää kielen kärjellä. Tällöin myös lehdykän värähtely lakkaa. Soittaja ei kuitenkaan lakkaa varsinaisesti puhaltamasta vaan pitää ilmanpainetta yllä. Kun soittaja irrottaa kielensä lehdykästä, se alkaa jälleen värähdellä, ja kuulemme uuden äänen. Tavanomaisilla kielityksillä äänet voidaan soittaa täyteen mittaansa tenutona tai lyhyemmiksi staccatona. Kaikkia ääniä ei tarvitse kielittää, vaan osa voidaan sitoa eli soittaa legatona. Kielitys voi olla myös hyvin huomaamaton ja miltei legaton kaltainen kuten portatossa. Lisäksi tunnetaan erilaisia tehokeinona käytettyjä kielitystapoja. Roachin (1998: 91) mukaan slap-kielityksessä kieli koskettaa lehteä laajemmalta alueelta. Kun ilma saavuttaa suukappaleen, kieli irrotetaan nopealla alaspäin suuntautuvalla liikkeellä. Syntyy voimakas sävelkorkeudeltaan epämääräinen ääni. Flutter-kielityksessä kieltä tärisytetään kitalakea vasten (Delangle \& Michat 1998: 174).

On olemassa myös joitakin muita kuin kielittämällä aikaansaatuja tehokeinoja kuten moniääni- eli multitone-tekniikka, jossa monta ääntä soi samanaikaisesti. Alaääniä voi pehmentää käyttämällä subtone-sävyä, joka saadaan aikaan vetämällä alaleukaa ja/tai huulta taaksepäin. Äänenkorkeutta voidaan muutella portaattomasti ansatsilla ja kurkunpäällä. Tällä tavoin saadaan aikaiseksi erilaisia glissandoja. (Ks. esim. Roach 1998; Liebman 1994: 37-40.)

Saksofonin äänialasta erotetaan usein eri rekistereitä. Voidaan puhua alarekisteristä, keskirekisteristä tai ylärekisteristä. Saksofonin tavallisemmin käytetyn rekisterin yläpuolelle ulottuvan altissimo-rekisterin käyttö on yleistynyt yhä enemmän 
1950-luvulta lähtien sekä afroamerikkalaisessa että taidemusiikissa. Altissimorekisterin voidaan katsoa alkavan fis-sävelestä kahden oktaavin ja kvintin etäisyydellä saksofonin matalimmasta äänestä, ja sen hallitseminen vaatii tarkkaa "sisäistä korvaa" ja erityisen hyvää kontrollia ansatsissa (Luckey 1992: 2-3). Saksofonin äänen muokkaamiseen ja hallintaan käytetyt keinot muodostavat kokonaisuuden, jossa osat vaikuttavat toisiinsa ja josta asiaan perehtymättömän kuuntelijan on vaikea erottaa kokonaisvaikutelmaan vaikuttavia tekijöitä omiksi osa-alueikseen.

Olen tietoisesti painottanut saksofonin äänestä puhuessani enemmän termiä saundi, kun olen käsitellyt jazzsaksofoninsoittoa, ja käsitettä äänenlaatu, kun olen puhunut klassisesta saksofoninsoitosta. Tämä johtuu toisaalta siitä, että saundi-sanaa käyttävät suomen kielessä yleensä eniten juuri jazz-, rock-, ja tanssimuusikot. Olen myös halunnut sanavalinnoillani korostaa eroa jazzsaksofoninsoiton ja klassisen tyylin ihanteiden ja käsitysten välillä. Tämä ei tarkoita, etteivät klassisen saksofonin soittajat käyttäisi saundin käsitettä. Klassinen saksofoninsoitto ja jazzsaksofoninsoitto eivät ole toistensa vastakohtia. Ne ovat erilaisia tapoja soittaa saksofonia. Saundi kuvaa sanana usein paremmin jazzsaksofoninsoittoa ja äänenlaatu paremmin klassista saksofoninsoittoa. Äänenlaatua voi helpommin käyttää myös neutraalimpana terminä, joka ei välttämättä viittaa kumpaankaan tyyliin.

\section{Ääni-ihanne}

Myös haastattelemani jazzsaksofonistit käyttivät saundi-sanaa viitatessaan saksofonin ääneen. Heinilä totesi kuitenkin puhuvansa usein mielellään "kvaliteetista". Tämä termi painottaa hänen mukaansa "asian laadukkuutta". Ei ole aivan selvää, mitä osa-alueita saundin tai äänenkvaliteetin sisälle luetaan. Muusikoilla on varmasti eriäviä mielipiteitä siitä, kuuluvatko esimerkiksi artikulaatio ja vibrato näiden käsitteiden rajojen sisäpuolelle. Haastattelemillani jazzsaksofonin opettajilla tuntuu kuitenkin olevan suunnilleen samanlainen tapa hahmottaa tätä asiaa. He kaikki pystyvät analyyttisesti erottamaan jonkin niin sanotun "perussaundin", "peruskvaliteetin" tai perusominaisuuden korvin havaittavasta kokonaisuudesta, mutta he pitävät myös tämän perusominaisuuden ulkopuolelle jääviä asioita kuten artikulaatiota hyvin oleellisina lopputuloksen ja äänestä saatavan kokemuksen kannalta. Näin esimerkiksi Aaltonen toteaa, että artikulaatio on hyvin ratkaiseva elementti äänessä tunnistaessamme soittajaa. Heinilän mielestä aluksi ei välttämättä ole pedagogian kannalta edes järkevää erotella osasia liikaa toisistaan. Hän antaisi mieluiten oppilaalle mahdollisuuden itsenäiseen oman äänen löytämiseen ilman turhaa asioiden mekanisoimista. Heinilän näkemys on, että perusominaisuus äänessä on todennäköisesti tahaton. Kokemuksen myötä ääntä oppii sitten purkamaan osasiksi ja osasten kautta voi vaikuttaa lopputulokseen haluamallaan tavalla. 
Lopullisen äänenlaadun riippuvuutta pienemmistä osatekijöistä tukevat hyvin myös Pylkkäsen näkemykset. Hän toteaa, että pelkkä "suora ääni" on aika pieni osatekijä siinä, miltä ääni todella kuulostaa. Jollakulla voi olla vähän "rupisempi" perussaundi, mutta jos "kielitys" ja "taimi" eli fraasien sijoittelu suhteessa perussykkeeseen ja "ne kaikki jutut siinä ympärillä" kuten "niekkujen" eli liukujen käyttö tai käyttämättä jättäminen ja "muut efektit" toimivat, lopputulos voi olla paremman kuuloinen.

Saundia voi lähestyä myös filosofisena kysymyksenä. Saundi ei välttämättä ole vain ääntä ja fysiikkaa, se voi olla vaikkapa itseilmaisua. Aaltosen mukaan saundi on sinänsä jo "valmis ilmaisu". Se ei siis ole pelkästään väline ilmaisuun. Hänen mielestään saundi on persoonan ilmaisu: Esimerkiksi John Coltranen saksofonisaundi kuvastaa hänen persoonaansa ja Lester Youngin saundi hänen persoonallisuuttaan ja kokemusmaailmaansa. Omaa olemustaan vastaan ei edes kannata taistella. Aaltonen toteaakin, että "paras voi olla vaan olemalla oma itsensä". Aaltoselle saundi on myös asenteen ilmaisu: "Sä et puhu vauvalle samoin kun jollein, joka yrittää ryöstää sun polkupyörääs."

Jazzmusiikissa instrumentalistin tai laulajan yksilöllistä ääntä onkin yleensä ainakin periaatteessa pidetty hyveenä. Hyvin vaikealta tuntuu määritellä, milloin äänenmuodostusasioissa on kysymys yksilöllisestä näkemyksestä, persoonallisuuden jatkeesta, sisimmän ilmaisusta tai henkilökohtaisesta mausta ja milloin vain kykenemättömyydestä hallita ääntä. Heinilä on havainnut tämän ongelman opetuksessa. Hänen mukaansa saksofonilla on mahdollista saada aikaan hyvin monenlaatuista ääntä, eikä opettajan henkilökohtainen mieltymys voi aina ratkaista sitä, mikä on hyvä oppilaan kannalta. Heinilän mielestä yksilöllisyys jazzissa korostuu nimenomaan saksofonin kohdalla. Hän huomauttaa, että tämän voi havaita tarkkailemalla, miten eri sektiot käyttäytyvät big band -kokoonpanossa. Juuri saksofonisektio on usein vaikein saada soimaan tasaisesti johtuen sen heterogeenisuudesta soittajien äänenlaatujen suhteen.

Saksofonisaundin muuttuvia rakennuspalikoita voivat olla $\mathrm{mm}$. intensiteetti, vibraton laajuus tai nopeus, kielityksen terävyys, yläsävelsarjan eri osien korostuminen, intonaatio jne. Näiden osatekijöiden summana vaikutelma voi olla hyvinkin erilainen. Se ei tarkoita kuitenkaan, etteivätkö esimerkiksiräikeä ja pehmeä ääni voisi kumpikin olla hyviä saundeja. Aaltosen kuvailemana Lester Youngin saundi on kevyt ja hauras ja John Coltranen saundi intensiivinen ja läpitunkeva. Molempien ääni on kuitenkin sellainen, kuin sen pitääkin olla. Se ikään kuin istuu soittajalleen.

Mielenkiintoista sinänsä on, että kokenut soittaja pystyy yleensä tuottamaan hyvinkin monenlaista ääntä instrumentillaan. Hän myös saattaa muunnella ääntä ilmaisullisissa tarkoituksissa ja musiikin ja esimerkiksi kokoonpanon mukaan. Kaikki haastattelemani jazzsaksofonistit olivat yhtä mieltä siitä, että näin on lupa tehdä, ja esimerkiksi Aaltosen mielestä on aivan olennaista, että saundi muuttuu soitettavan 
musiikin esteettisten vaatimusten mukaan. Kyky muuttaa ääntä voi olla joillekin myös ammattitaidon mitta. Esimerkiksi studiomuusikkoa saatetaan pyytää soittamaan "kuin David Sanborn”. Persoonallisuuden rajat ovatkin laajemmat, kuin miltä alkuun näyttää. Kuitenkin soittajan äänessä säilyy usein jokin tunnistettava piirre, ikään kuin sormenjälki. Heinilä hahmottaa tätä asiaa jokaisen yksilöllisenä tapana koskettaa soitinta. Hän kertoo soittaneensa levylle sopraanosaksofonia tenorisaksofonin suukappaleella ja päässeensä näin äänellisesti hyvin erikoiseen lopputulokseen, josta pystyi kuitenkin tunnistamaan itsensä.

Saksofonin ääntä koskevia ihanteita kuvaillessaan haastatellut käyttivät monenlaisia kielikuvia. He mainitsivat myös soittajia, joilla heidän mielestään oli hyvä saundi. Aaltonen mainitsi mm. Coltranen, Youngin, Coleman Hawkinsin ja Sonny Rollinsin ja Heinilä puhui Jan Garbarekista. Kaikki mainitut ovat yleisesti arvostettuja taiteilijoita. Kaikki haastatellut jazzsoittajat tuntuvat arvostavan saundia, jossa on kapasiteettia, ilmaisullista reserviä, varaa tehdä asioita. Soittajan tekniikka ei siis saisi jämähtää yhteen pisteeseen. Mitään ei saisi lukita, vaan mahdollisuudet pitäisi pitää auki. Aaltonen vertaa tätä äänitysstudion äänipöydän toimintaan: jos haluaa rakentaa saundia esimerkiksi tummempaan suuntaan, täytyy olla tekniset valmiudet toteuttaa muutos. Heinilän mielestä olennaista on, että "soittaja viihtyy soittimensa kanssa". Hänen mielestään liiallinen esikuvien seuraaminen voi olla haitallista, sillä esimerkiksi välineet ja ihanteet, jotka toimivat esikuvan kohdalla, eivät välttämättä toimi itsellä. Hän toteaa myös muodin vaikuttavan välillä haitallisesti. Tästä esimerkkinä on mm. ylärekisterisoiton painottuminen alempien rekisterien hallinnan kustannuksella. Heinilä puhuukin tasapainoisen, kaikissa rekistereissä soivan saksofonin äänenlaadun puolesta.

Klassisen saksofoninsoiton alueellakaan saksofonin ääneen liittyvä terminologia ei ole yksiselitteistä. Ei ole olemassa yhtä oikeata termiä saksofonin ääntä tarkoittamaan. Savijoki korostaakin, että itse asialla on merkitystä, ei niinkään sillä, käytetäänkö korrekteja termejä. Hän toteaa saundi-termin kuuluvan enemmän kevyen musiikin sanastoon ja haastateltavat puhuvatkin sointiväreistä, äänenlaadusta ja äänenkvaliteetista. Silti myös saundi-sanaa käytetään paljon.

Vaikka haastatelluille klassisen saksofoninsoiton pedagogeille monet saksofonin ääneen liittyvät ihanteet ovat yhteisiä, he hahmottavat saksofonin ääntä hiukan eri tavoin käsitteellistäessään sitä. Savijoki ei halua teoretisoida asiaa liikaa, vaan tyytyy toteamaan, että klassiseen ranskalaistyyliseen saksofoninsoittoon kuuluu tietynlainen ihanne äänestä, jonka toiset onnistuvat myös käytännössä aikaansaamaan. Vibrato on olennainen osa tätä ihannetta, samoin sävelpuhtaus. Savijoki ei lue artikulaatiota varsinaisesti kuuluvaksi tähän kokonaisuuteen vaan pitää sitä omana alueenaan. Keikkonen näkee äänenlaadun kokonaisuuden koostuvan "perussaundista" eli "ytimestä", joka on pohjana hienovaraisemmille sävyn ym. muutoksille, vibratosta "mausteena" ja artikulaatiosta, joka on "sointimateriaalin käsittelyssä tärkeä osa" ja "suurin haaste ja ongelma". 
Haastatellut antavat värikkäitä kuvauksia hyvästä saksofonin äänestä. Tuomisalon mielestä hyvä äänenkvaliteetti on "puhtaasti soitettu" ja siihen kuuluu "kuulas pohjasaundi johon lisätään hyvä tasainen hallittu vibrato", joka ei ole "liian iso" ettei se kuulostaisi "mäkättävältä" ja, johon ei kuulu "särinöitä". Keikkonen pitää "mehukkaasta, paksusta, täyteläisestä saundista". Savijoen opettaja Daniel Deffayet tuntuu tehneen suuren vaikutuksen sekä Savijokeen itseensä että Keikkoseen, joka on myös opiskellut muutamia kertoja Deffayet'n johdolla. Hyvästä saksofonin äänestä kysyttäessä Savijoki totesi aluksi ykskantaan, että "se on sellanen kun Daniel Deffayet'lla on". Deffayet'n "lämmin ja pyöreä" ääni muistuttaa Savijoen mukaan laadultaan hyvin paljon jousisoittimia ja varsinkin sellon ääntä. Deffayet onkin myös viulisti. Keikkonen kuvailee Deffayet'n äänenlaatua "notkeaksi tynnyrisaundiksi". Hänen mukaansa tämä eroaa jonkin verran nykyaikaisesta ranskalaisesta sointi-ihanteesta, joka on "pienempi" ja "kirkkaampi". Tämä selittyy ainakin sillä, että saksofoni pyritään orkesterissa saamaan soimaan klarinettien ja huilujen kanssa saumattomammin yhteen.

Kaikki haastatellut korostavat sävelpuhtauden eli vireisyyden merkitystä äänenlaadun osatekijänä. Tuomisalon mukaan on hyvin harvinaista kuulla puhdasta saksofoninsoittoa. Sävelpuhtauden vaatimus on siis suuri haaste. Savijoki toteaakin, että puhtaudessa on ikään kuin normaalin puhtaasti soittamisen yläpuolella olemassa "porras", jolloin soitto on aivan erityisen puhdasta. Tällaisen erityisen puhtauden voi havaita. Sen perusteella voi ehkä jopa tunnistaa soittajan. Tällöin puhtaus on erottamaton osa äänenlaatua. "Mitä puhtaampaa se soitto on, sitä hienommalta se kuulostaa."

Vaikka yksinkertaistettuna helposti näyttää, että klassisessa saksofoninsoitossa kaikki soittajat yhden koulukunnan sisällä pyrkivät melko samanlaiseen ääneen, ei äänen itseilmaisullista puolta voi tässäkään jättää huomiotta. Savijoen mukaan se miltä soitto loppujen lopuksi kuulostaa on puhtauden, musikaalisuuden ja vibraton yhdistelmä. Äänenlaatua ei pitäisi ajatella erillisenä asiana. Se on yksi osa hyvää soittoa, johon Savijoen mukaan liittyy myös paljon muita asioita kuten soitossa oleva "lämpö", "suuri sisältö" ja musikaalisuus. Näihin saattavat vaikuttaa kontaktit opettajiin, musiikin tuntemus ja muu sivistys. Hyvä äänenlaatu on kuitenkin Savijoen mielestä toisaalta myös asia, joka soittajalla joko on tai ei ole, toisin sanoen lahjakkuusasia.

Ei ole siis lainkaan yksiselitteistä, mitä saksofonin ääni klassiselle saksofonistille merkitsee. On olemassa tietty ihanne, estetiikka ja tietyt säännöt, joista kaikki tuntuvat ainakin periaatteessa olevan suunnilleen samaa mieltä. Kuitenkin soittajat ovat erilaisia ihmisiä, joilla on erilainen persoona ja erilaiset kokemukset. Kyse lieneekin tasapainottelusta estetiikan normien ja omien näkemysten, edellytysten, lahjojen ja rajoitusten välillä. Savijoki kiteyttääkin asian toteamalla, että "täytyy erottaa ne asiat, että ihmiset on erilaisia myös siinä, mistä ne tykkää ja mistä ne ei tykkää." Saksofonisti voi siis hyväksyä toisen saksofonistin persoonan vaikutuksen äänessä, mutta äänestä ei tarvitse silti pitää. On siis eri asia, mistä saksofonistit pitävät ja mitä sakso- 
fonistin on sallittua tehdä. Soittaminen voi olla ammattitaitoista olematta kuitenkaan kaikkien mielestä koskettavaa.

Keikkonen osallistuu persoonallisuuskeskusteluun toteamalla, että persoonallisuus ei saisi vaikuttaa negatiivisessa mielessä: "Jos ei saa sanaa suustaan puhumalla, kyl se kuuluu sitten soitonkin läpi, et se on sitten vähän semmosta arkista kituuttamista." Hänen mukaansa "vaatii tietynlaista poweria henkilönä, että on karismaa puhaltaa sitä ääntä ulos”.

Haastateltavat ovat hiukan eri mieltä siitä, miten paljon saksofonin äänenlaatua sopii muokata soitettavan musiikin mukaan. Savijoki näkee, että kaikkea musiikkia pitäisi soittaa hyvällä äänellä, jolle on olemassa määritelmät musiikin lajista riippumatta. Hän korostaa hyvän äänenlaadun tärkeyttä myös nykymusiikkia soitettaessa. Yksi perusero äänen suhteen voi joskus esiintyä: säveltäjän toivomuksesta saksofonisti voi soittaa ilman vibratoa. Keikkonen näkee äänen muokkaamisen mahdollisuudet hiukan laajemmin. Hänen mukaansa modernissa musiikissa käytetään usein suorempaa ääntä ja artikulaatio on selkeämpää. Kvartettisoitossa äänenkvaliteettia muutetaan yhdenmukaisempaan suuntaan. Orkesterisoitossa saksofonistit joutuvat toisinaan toteuttamaan kapellimestarien joskus hyvin outojakin toiveita, ja kevyemmässä klassisessa musiikissa voidaan käyttää ääntä, jossa on vaikutteita jazzsoitosta.

\section{Äänenmuodostuksen tekniikka}

Olen jakanut tarkastelua helpottaakseni saksofonin äänenmuodostuksen tekniikan viiteen eri osa-alueeseen. Nämä ovat hengitys, ansatsi, kurkku, artikulaatio ja vibrato. Näihin parametreihin olen törmännyt toistuvasti sekä saksofoninsoittoa käsittelevässä kirjallisuudessa (mm. Liebman 1994; Tiel 1963), että keskusteluissani saksofonistien kanssa. Kaikki opettajat eivät halua lukea artikulaatiota äänenmuodostuksen osaksi. Omat kokemukseni käsitteen hyödyllisyydestä äänenmuodostuksen opetuksessa tukevat kuitenkin sen mukanaoloa. Mielestäni myös soittoasennolla on ratkaiseva merkitys äänenlaadun kannalta. Haastateltavat puhuivat asennosta kuitenkin enimmäkseen muiden osa-alueiden kuten kurkun käytön tai hengitystekniikan yhteydessä, joten en katsonut tarpeelliseksi nostaa sitä analyysissäni erilliseksi alueeksi.

\section{Hengitys}

Toimiva hengitystekniikka on hyvin keskeinen tekijä minkä tahansa puhallinsoittimen soitossa. Aaltonen toteaakin, että hyvällä hengitystekniikalla voi jopa paikata lieviä puutteita esimerkiksi ansatsissa. Haastatellut tuntuvat olevan melko samoilla linjoilla 
saksofoninsoitossa käytettävän hengitystekniikan suhteen, joskin he kuvailevat asiaa hieman eri tavoin. Kaikki he pitävät hengitystä keskeisenä asiana soittamisen kannalta ja neuvovat paneutumaan siihen huolella. Heinilän mukaan hyvä hengitys perustuu hyvään soittoasentoon. Selkä tulisi pitää suorassa ja hartioiden pitäisi pysyä alhaalla selän leveydellä. Sisään hengittäessä kannattaa hänen mukaansa kiinnittää huomiota juuri siihen, että hartiat eivät nouse ylös. Sisäänhengityksen suunta on alavatsasta rintakehän suuntaan. Uloshengitys tapahtuu Heinilän mukaan päinvastoin, ikään kuin "puristaisi pesusienen kasaan". Hän korostaa myös, että hengitys ei saisi olla liian mekaaninen asia.

Mekaanisuutta vastaan puhuu myös Pylkkänen todetessaan, että tekniikoita saman asian toteuttamiseksi on olemassa useita ja että tästä johtuen hengitystekniikka on hyvin laaja kysymys. Pylkkänen toteaa ns. palleahengityksen olevan kuitenkin keskeinen tekniikka saksofoninsoitossa. Tässä hengityksessä "pallea supistuu liikkuen kohti vatsaonteloa ja keuhkot täyttyvät ilmalla". Uloshengityksessä "pallea rentoutuu ja palautuu takaisin kohti rintaonteloa" ja samalla ilma vapautuu keuhkoista.

Aaltosen näkemyksessä hengityksen tulee tapahtua ennen kaikkea rennosti ja luonnollisesti. Se ei saisi olla suoritus vaan parhaimmillaan se on olotila. Kuten Heinilä, Aaltonenkin korostaa asennon merkitystä: soittajalla pitäisi olla tukeva olo. Sisään hengittäessä kannattaa varoa ottamasta liikaa ilmaa. Hengityksen tuki voi olla kokonaisvaltainen tunne, jossa jalat ovat tukevasti maassa ja tuki alhaalla. Hengitystä ei pitäisi kuitenkaan väkisin yrittää "painaa alas" tai "nostaa ylös" esimerkiksihartioita nostamalla, vaan kaiken pitäisi tapahtua mahdollisimman levon omaisessa tilassa. Aaltonenkin toteaa erilaisten hengitystekniikoiden mahdollisuuden ja mainitsee mm. itse käyttävänsä mielikuvaa oopperalaulajasta kuvaamassa yhdenlaista melko kokonaisvaltaista lähestymistapaa hengitykseen.

Perusperiaatteiltaan hengitystekniikka klassisessa saksofoninsoitossa ei eroa muiden puhallinsoittimien tai jazzsaksofoninsoiton hengitystekniikasta. Savijoki pitää hengitystä sinänsä hyvin yksinkertaisena tapahtumana: "Vedetään ilmaa sisään ja puhalletaan ulos." Hän erottaa varsinaisesta hengityksestä ajatuksen tuesta, jolla tarkoitetaan sitä, että äänen takana on riittävästi ilmanpainetta tukena. Tuen avulla fraasit pysyvät koossa ja äänet voidaan tuottaa halutulla voimakkuudella. Savijoki vertaa tukea jousisoittajan jousikäden tasaisuuteen.

Myös Keikkosen mielestä hengitys on yksinkertainen asia. Ilma tulisi saada mahdollisimman alas niin, että kädellä vyötäröltä koettaen hengityksen pitäisi tuntua myös selkäpuolella. Keikkonen korostaa tässä tuntemuksen tärkeyttä ja vertaa hengityksen luomaa tuntemusta mielikuvaan tynnyristä, joka on täynnä. Hänenkin mukaansa hyvällä hengitystekniikalla "voidaan kompensoida pieniä virheitä kurkussa ja ansatsissa". 


\section{Ansatsi}

Ansatsin osalta jazzsaksofoninsoitossa on useimmiten pyritty rentouteen, luonnollisuuteen ja liikkuvuuteen. Tämä näkyy myös haastateltujen näkemyksissä. Hengityksen tapaan ansatsikin on Aaltoselle rentouteen liittyvä kysymys. Hänen mukaansa kannattaa pyrkiä ansatsiin, jossa suukappale on mahdollisimman luonnollisesti suussa ilman turhia lihasjännityksiä niin, että ilma pääsee kulkemaan suukappaleeseen esteettömästi. Suukappale vain työnnetään suuhun ja suu laitetaan kiinni ilman, että alahuulta käännetään sisään tai ulos. Alahuulen on tarkoitus myötäillä äänenmuodostuksessa hienovaraisella eteen ja taakse päin rullaavalla liikkeellä. Tämä alahuulen ohjaava tuki on Aaltosen mukaan olennaisen tärkeä. Hän toteaa, että saksofonin lehti pääsee värähtelemään parhaiten, kun siihen kohdistuva puristus on mahdollisimman pienellä alueella, niin että sitä peitetään mahdollisimman vähän. Olennaista on myös huomioida yksilöllinen anatomia ansatsiin vaikuttavana tekijänä. Esimerkiksiulkoneva leuka saattaa vaatia erityistä tarkkuutta ansatsia opeteltaessa.

Pylkkäsen näkemys ansatsista muistuttaa hyvin paljon Aaltosen ajatuksia. Hän näkee, että "ns. jazzsaksofoninsoitossa pyrkimyksenä on aikaansaada kimmoisa ja elastinen ansatsi, jolla pystyy muokkaamaan ääntä haluttaessa, joko intonaation vuoksi tai efektinä". Tällainen ansatsi on mahdollinen, jos turha jännitys alahuulesta ja leuasta saadaan pois. Pylkkänen toteaa myös, että äänenmuodostuksen onnistumiseksi suussa pitäisi olla riittävästi "tilaa”, jotta ääni voisi soida vapaammin. Tähän vaikuttaa erityisesti kielen asento, jonka Pylkkänen neuvoo pitämään i-äännettä vastaavana. Aaltosen tavoin Pylkkänen korostaa alahuulen kontrollia, johon hänen mukaansa myös kurkku ja äänihuulet osallistuvat.

Myös Heinilä pitää tärkeänä ansatsin rentoutta ja luonnollisuutta. Hän toteaa, että ansatsin toimivuuden voi testata sillä, pystyykö soittaja liikkumaan eri rekistereissä vaivattomasti mahdollisimman pienin suun alueen muutoksin. Esimerkiksi alarekisterissä ei tällöin tarvitsisi vetää leukaa taaksepäin kovin paljoa. Leuan ja huulten ei pitäisi myöskään väsyä helposti, jos ansatsi on kunnossa. Heinilä korostaa henkilökohtaisten anatomisten ominaisuuksien kuten ulkonevan tai sisäänpäin kääntyvän leuan tai huulten koon merkitystä ansatsin kohdalla.

Perinteisesti klassisessa musiikissa saksofonin ansatsi on ollut tiukempi kuin jazzissa, rhythm and bluesissa tai rockissa. Kaikki tätä kohtaa varten haastattelemani saksofonistit ovatkin yhtä mieltä siitä, että ansatsin tulee olla tiukka. Näkemyksistä löytyy kuitenkin pieniä aste-eroja. Mm. Savijoki kuvailee toimivaa saksofoniansatsia "erittäin tiukaksi": instrumentti ei pääse liikkumaan lainkaan. Hän kertoo opettajansa Daniel Deffayet'n silloin tällöin napauttaneen sormella oppilaan soittimeen testatakseen, liikkuuko soitin. Hänen mukaansa alahuulen tulee olla alahampaiden päällä ja ylähampaiden kokoajan kiinni suukappaleessa. Tiukka ansatsi on siis sävelpuhtauden ja äänen laadukkuuden edellytys. 
Tuomisalon mukaan sopiva paikka alahuulelle ansatsissa on "tasan hampaiden päällä niin, että se ei mene yhtään yli, mutta ei myöskään jää vajaaksi”. Ihannepaikka on "millin osista kiinni". Tuomisalo epäilee käyttävänsä ylärekisterissä hiukan opettajansa Savijoen tyylistä poikkeavaa tekniikkaa, jossa hän siirtää "alahampaiden ja alahuulen muodostamaa kompaktia pakettia hiukan eteenpäin".

Savijoesta poiketen Keikkonen sallisi voimakkaan pystypurennan lievän löysäämisen, mutta hänen mukaansa tämä toimenpide vaatisi, että ansatsi on sivuilta tiukempi. Hän kuvailee toimivaa ansatsia kiinteäksi paketiksi suukappaleen ympärillä: ylähampaat ovat tiukasti kiinni, alahuuli käännetään alahampaiden päälle, leuka jännitetään alaspäin peruspurentaan ja lihakset suun sivuilta supistetaan kuten äännettäessä "tyy".

\section{Kurkku}

Yleinen näkemys kurkun toiminnasta saksofoninsoitossa on, että se pitäisi pitää avonaisena ja rentona, jotta se toimisi hyvin automaattisesti mukautuen äänenmuodostuksen vaatimuksiin. Näin esimerkiksi Pylkkäsen mukaan "kurkkua tulisi lähinnä käyttää passiivisesti”. Kurkulla ei siis varsinaisesti tehdä mitään saksofoninsoitossa vaan "äänten tulisi tuntua kurkussa". Kurkun pitäisi siis olla rento. Tähän asiaan liittyvät Pylkkäsen ansatsin kohdalla mainitsemat kielen asento ja alahuulen kontrolli.

Heinilä toteaa kurkun toiminnan olevan riippuvainen ennen kaikkea pään asennosta. Hän neuvookin tutkimaan asiaa tarkastelemalla, mitä puheäänelle tapahtuu, jos päätä viedään eteen tai taakse päin. Heinilän mukaan soittajat pitävät usein päätä liian edessä.

Myös Aaltonen katsoo kurkun toimivan parhaiten rentona. Hänen mukaansa kurkku voi olla myös liian auki, ikään kuin pakotettuna, jolloin se ei enää ole rento. Parhaimmillaan kurkun toiminta tapahtuu tiedostamatta. Miehillä aataminomena ikään kuin kelluu: se ei ole ylhäällä eikä myöskään alhaalla vaan jossakin välillä.

Jazzsaksofonistien tavoin haastatellut klassisen saksofonin taitajat korostavat kurkun avonaisuutta. Savijoen mukaan kurkun pitäminen leveästi auki on ehdottoman tärkeää, muuten äänenlaatu ja puhtaus kärsivät. Keikkonen näkee, että kurkku voi olla liiankin auki. Hän sanookin, että kurkku "ei ole mikään viemäri". Sen tulisi toimia pienin tiedostamattomin liikkein. Esimerkiksialtissimorekisterissä kurkunpään asennon on muututtava hieman.

\section{Artikulaatio}

Artikulaatiota ei haluta aina laskea puhaltimien äänenmuodostukseen kuuluvaksi asiaksi. Jazzsoittajat tuntuvat kuitenkin usein pitävän artikulaatiota olennaisena ja erottamattomana osana kokonaisuutta, jota voidaan kutsua tunnistettavaksi ja yksilöl- 
liseksi saksofonisaundiksi. Vibraton tavoin kielitys kuuluu Heinilän mielestä jazzsaksofoninsoitossa tiedostamattomampien asioiden joukkoon. Hän ohjaa oppilasta harjoittelemaan kielitystä "mahdollisimman monipuolisesti ja varioiden". Pylkkäsen mukaan jazzsaksofoninsoitossa artikulaatio perustuu "kielitykseen sekä puhalluksen antamaan tukeen", joiden suhde vaihtelee "tyylistä ja halutusta saundista riippuen". Hän toteaa, että mm. 40-50-lukujen jazzmusiikissa on ollut tapana korostaa iskuttomia ääniä kahdeksasosakuluissa usein ilmalla kielen sijaan. Nopea ja napakka kielitys on mahdollinen, kun kielen kärki pidetään alhaalla ja kanta ylhäällä.

Aaltonen pitää artikulaatiota erittäin oleellisena seikkana saksofonistin tyylin ja tunnistettavuuden kannalta. Hyvässä artikulaatiossa kielen kosketus lehteen on mahdollisimman puhdas eli, kun "kieli koskettaa niin se koskettaa ja kun ei niin ei". Epämääräisestä kielen kosketuksesta on seurauksena suttuisuutta soittoon ja ylimääräistä hälyä, "rahinaa ja rohinaa". Aaltonen vertaa hyvää kielen toimintaa viulistin harjaantuneeseen jousikäteen tai rumpalin viimeisteltyyn virvelitekniikkaan. Hyvään kielitykseen kuuluu Aaltosen mukaan myös fraasien laulavuus. Kielitys ei siis saa toimia tukahduttavana elementtinä tai jarruna. Staccatonkin pitäisi olla laulava.

Klassisen tekniikan osalta haastateltavat suhtautuvat hiukan eri tavoin siihen, missä mielessä artikulaatio mielletään varsinaisen äänenmuodostuksen osaksi. Savijoki ei lue artikulaatiota keskeiseksi äänenmuodostuksen osa-alueeksi, kun taas Keikkonen toteaa sen olevan merkittävä osa saundia "sointimateriaalin käsittelyn" kautta. Savijoki haluaa pitää erillään myös aksentit ja artikulaation.

Toisin kuin usein jazzsaksofoninsoitossa Savijoen mukaan artikulaatio "tapahtuu vain ja ainoastaan kielellä”. Tuki ei siis saa osallistua. Näin artikulointi on vain pitkän äänen pätkimistä. Ansatsi pidetään paikallaan ja kurkku auki. Keikkonen kuvaa saksofonin artikulaatiota ääntämällä tavut "ty-ty-ty-ty" ja "tyy-tyy-tyy".

\section{Vibrato}

Vibrato on varmasti kiistellyimpiä osa-alueita saksofonin äänenmuodostuksessa. Tarjolla tuntuu olevan monenlaisia tekniikoita ja ihanteita. Osa haastatelluista suhtautuukin varovaisesti aiheeseen. Pylkkänen toteaa vibraton tekemiseen olevan monia eri mahdollisuuksia ja mainitsee mm. leualla ja ansatsilla tehtävän vibraton. Heinilä toteaa vibraton olevan usein melko tiedostamaton asia jazzsaksofonistin soitossa. Vibrato tuo soittoon tunnistettavuutta, mutta silti Heinilä neuvoo soittajaa harjoittelemaan paljon ilman vibratoa, jotta tälle kehittyisi taito tarvittaessa säännöstellä ja kontrolloida sitä.

Aaltosella on melko selkeät näkemykset vibraton suhteen. Hän neuvoo saksofonisteja kuuntelemaan oopperalaulajia ja saksofonin vanhoja mestareita hyvän vibraton aikaansaamiseksi. Hänen mukaansa hyvä vibrato on eräänlainen alahuulen liikkeellä synnytetty pulssi, joka syntyy enemmän äänenvoimakkuuden kuin äänenkorkeuden 
vaihteluista. Tätä vaihtelua ja liikettä Aaltonen kuvaa "faf-faf-faf" -ääntämyksen avulla. Erityisen hyvin tällainen vibratotekniikka on kuultavissa mm. Ben Websterin soitossa, mutta samalla tekniikalla saadaan aikaiseksi laaja valikoima erilaisia vibratoja. Tekotavaltaan hienovarainenkin vibrato muistuttaa trumpetinsoittajien shake-efektiä, joka on eräänlainen huulitrilli.

Klassisessa saksofoninsoitossa vibrato on hyvin keskeinen elementti, jonka harjoittelemiseen monet käyttävät paljon aikaa. Vibrato on esityksessä enemmänkin sääntö kuin poikkeus. Tuomisalo kertookin suuren osan opetuksessa käytettävästä ajasta kuluvan "kultaisen vibraton etsimiseen". Hän toteaa hyvän vibraton vaativan perustuksekseen hyvän "kuulaan pohjasaundin". Tähän lisätään "tasainen hallittu vibrato, johon ei tulisi särinöitä". Vibrato ei saisi myöskään olla liian iso, jotta se ei kuulostaisi "mäkättävältä".

Savijoki pitää vibratoa mekaanisena asiana. Hänen mukaansa paras vibrato saadaan aikaan alahuulella niin, että ansatsia löysätään vain hiukan. Äänenkorkeuden vaihtelu tapahtuu äänen alapuolella, ei molemmin puolin. Savijoki toteaa, joidenkin soittajien kokeilleen myös palleavibratoa saksofoninsoitossa, mutta hänen mukaansa se ei toimi.

\section{Opetusmenetelmät}

Jazzopetus on vielä niin nuorta, että menetelmät eivät ole opettajien välillä aina kovinkaan yhdenmukaisia. Osa opettajista ei ole opiskellut opettamista lainkaan. Tämä on Pylkkäsen mielestä ongelma, sillä pedagogiikkaan perehtymättömällä opettajalla saattavat keinot loppua helposti kesken, jos oppilas ei opikaan kuten muut. Opettamisessa on lähinnä kahta suuntausta. Oppilasta voidaan joko auttaa löytämään oma äänensä tai pyrkiä ohjaamaan johonkin tiettyyn suuntaan. Kaikki haastatellut ovat ensimmäisen vaihtoehdon kannalla. Esimerkiksi Heinilä kertoo jopa soittavansa malliksi mahdollisimman vähän, jotta hänen oppilaansa eivät alkaisi kuulostaa häneltä itseltään. Opettajalla, jolla ei ole riittävästi opettamista koskevaa näkemystä, ei ole muuta vaihtoehtoa kuin soittaa malliksi.

Tämä ei tietenkään tarkoita, etteikö olisi tarpeellista ja hyödyllistä soittaa oppilaalle malliksi varsinkin opiskelun alkutaipaleella. Yksi jazzopetuksen tärkeimmistä metodeista on transkriptioiden tekeminen jazzin mestarien levytetyistä improvisaatioista (ks. esim. Liebman 1996: 179). Näitä transkriptioita ei tyydytä ainoastaan nuotintamaan, vaan ne on tarkoitus opetella soittamaan mahdollisimman tarkasti alkuperäisen esikuvan mukaan. Tällöin on kiinnitettävä erityisesti huomiota siihen, miten jokin on soitettu. Toisin sanoen nyanssit, artikulaatio, fraseeraus ym. pyritään tuottamaan mahdollisimman hyvin alkuperäistä kuulokuvaa vastaavaksi. Haastatellut korostavat kuitenkin, että transkriptiomenetelmän kohdalla laatu korvaa määrän. Transkriptioita 
ei siis välttämättä tarvitse tehdä kovin monta oppiakseen jazzmusiikin perusasiat. Muiden soittajien improvisaatioiden opettelemisen ei siis pitäisi olla mikään itsetarkoitus. Omaa ilmaisua, jossa persoonallinen saundi on merkittävä osa, pitäisi lähteä hakemaan myös muilla keinoin - ensisijaisesti improvisoimalla.

Oppilaiden oppimistavoissa on eroja, samoin heidän vahvuuksissaan ja heikkouksissaan. Aaltosen mukaan joku oppilas saattaa heti saada tuotettua melko rennosti hyvän äänen, mutta ei saa sormia toimimaan. Toisella oppilaalla sormet toimivat, mutta saundi on kireä. Oppilaat vaativatkin haastateltujen mukaan yksilöllistä ja joustavaa opetusta. Aaltonen vertaa tällaista opettajan ja oppilaan suhdetta lääkärin ja potilaan väliseen kanssakäymiseen: "Kysytään potilaalta mikä vaivaa." Tämä lähestymistapa muistuttaa Aaltosen mielestä myös insinöörin työtä. Ongelmat pyritään purkamaan alkutekijöihinsä ja ratkaisemaan yksi kerrallaan. Ongelma voi siis olla vaikka tukkoinen perussaundi ja osanen, josta se johtuu, joustamaton ansatsi. Ratkaisu ongelmaan voi olla tietoinen ansatsin harjoittelu esimerkiksi jonkun ääniharjoituksen avulla.

Yksi jazzopetuksen ongelmista on jazzmusiikin improvisaatioluonne. Heinilän mukaan ongelman ydin on siinä, että improvisoidussa musiikissa "sisältö ja tulkinta luodaan samaan aikaan". Opetuksessakin pitäisi toisaalta keskittyä tarkastelemaan sitä, miten soitetaan eli ns. tulkintaa ja toisaalta pitäisi kiinnittää huomiota myös improvisaation rakentamiseen eli sen sävellykselliseen puoleen - sisältöön. Kuitenkaan näitä asioita ei todellisuudessa voi erottaa toisistaan. Nehän tapahtuvat yhtä aikaa. Näin ollen äänenlaatukin on riippuvainen esimerkiksi improvisaation harmonisista jännitteistä ja päinvastoin. Sama on tietysti totta ennalta sävellettyjen teosten esittämisessä, mutta niitä on aina kuitenkin helpompi tarkastella etukäteen ja erillään esittämisestä. Improvisaatiosta häviää tuoreus, jos siinä pelataan liian varman päälle. Kuitenkin esimerkiksi jazzimprovisaationkin odotetaan noudattavan tiettyjä lainalaisuuksia.

Kaikki haastatellut korostavat perusasioiden hallintaa opetuksen tavoitteena. Perusasiat toimivat pohjana mahdollisimman vapaalle ja persoonalliselle itseilmaisulle. Heinilä kertoo havainneensa hyvin yksinkertaisten harjoitusten hyödyllisyyden äänenlaadun kehittämisen kannalta. Hän neuvoo oppilaitaan soittamaan paljon rubato-rytmissä omaa luonnollista tempoa etsien, sillä silloin on mahdollista keskittyä intensiivisesti ääneen. Hän kertoo soitattavansa oppilaillaan paljon yksinkertaisia klassisia etydejä siinä tarkoituksessa, että saksofonin kaikki rekisterit saataisiin soimaan tasaisesti ja kaikki äänet tulemaan helposti mahdollisimman pienillä muutoksilla ansatsissa ja muualla. Tällaisessa harjoituksessa ei siis kiinnitetä huomiota tulkinnalliseen puoleen vaan ainoastaan soittamisen helppouteen, rentouteen ja tarkkuuteen. Myös Aaltonen neuvoo oppilaitaan usein soittamaan pitkiä ääniä asennoitumalla niihin rentousharjoituksina. Tarkoitus on oppia tuottamaan hyvää ääntä mahdollisimman vähällä vaivalla, ei lihasten kasvattaminen leukaan tai huuliin. Aaltonen täsmentää, että soittamisen opettaminen on oikeastaan sitä, että pyritään poistamaan oppilaan soitosta ja 
olemisesta soiton aikana kaikki turha pois. Turhaa on tässä tapauksessa kaikki se, mikä ei kuulu ihmisen luontaiseen olemukseen eikä paranna lopputulosta soittajan haluamalla tavalla.

Opetustilanteessa pyritään siis poistamaan oppilaalta turhia jännityksiä, jotka haittaavat soittamista. Usein ei ole edes väliä sillä, mitä soitetaan, vaan sillä, miten. Pylkkänen toteaakin, että sinänsä ihan käypä opiskelumenetelmä voi olla ottaa nuotti, alkaa soittaa sitä ja miettiä sitten, mitä parannettavaa löytyisi ja millä keinoin parannus toteutettaisiin. Jazzopetus on klassiseen opetukseen verrattuna vähemmän progressiivista. Heinilän mukaan improvisoidun musiikin opetuksessa ei sen improvisaatioluonteen vuoksi ole olemassa selkeää kuvaa siitä, mitä kaikkea pitäisi oppia. Joku soittaja voi kenties pärjätä hieman vähemmilläkin teknisillä taidoilla kompensoiden niitä vaikkapa vahvalla melodisella kekseliäisyydellään. Klassisessa musiikissa on olemassa tietty harjoitus- ja esitysrepertuaari, jota kaikki oppilaat käyvät läpi. Myös jazzmusiikissa on olemassa tietty repertuaari tärkeitä sävellyksiä, mutta opetuksen painopiste ei kuitenkaan ole mahdollisimman monen kappaleen oppimisessa vaan tavassa, jolla näitä sävellyksiä käsitellään improvisoinnin materiaalina.

Klassisen saksofoninsoiton äänenmuodostuksen opetuksessa käytetyt menetelmät kuvastavat hyvin haastateltujen ajatuksia saksofonin äänestä. Perusasiat eivät juurikaan tunnu muuttuvan, sillä ihanteet ovat melko selkeitä, samoin tekniikka niiden toteuttamiseksi. Savijoki korostaakin lahjakkuuden ja musiikillisen sivistyksen merkitystä todetessaan, että kaikkia oppilaita on opetettu samalla tavalla erilaisin tuloksin. Hyvä äänenlaatu ei hänen mukaansa ole taito, jonka vain voi opetella ja jonka sitten osaa. Se vaatii jotakin muuta. Perusasiat voidaan opettaa hyvin pienessä ajassa, mutta aina ei saada hyvää ääntä aikaiseksi vaikka tehtäisiin töitä kuinka paljon tahansa. Hedelmällistä on, jos soittaja pystyy suhtautumaan tekemiseensä enemmän kokonaisuutena - musiikin tekemisenä - eikä ainoastaan saksofoninsoittona. Savijoki rohkaiseekin oppilaitaan kuuntelemaan paljon musiikkia ja tutustumaan koko klassisen musiikin traditioon.

Opetusmateriaalina klassisessa saksofoninsoitossa käytetään mm. joitakin etydikokoelmia kuten Lacourin, Ferlingin tai Mulen etydejä. Tuomisalon mukaan on erityisen hedelmällistä käyttää aluksi äänen kehittämiseen hitaita etydejä. Nykysoittotekniikoiden opiskeluun käytetään erillisiä kirjoja. Esimerkiksi ylä-ääniharjoituksia löytyy Rascherin teoksesta Top tones for the saxophone (1977). Savijoki korostaa asteikkojen soittamisen tärkeyttä opiskelun osana. Soitin ikään kuin käydään läpi soittamalla esimerkiksi kaikki duuri- tai molliasteikot sekä kolmi- ja septimisoinnut saksofonin perusäänialan ääripäihin asti. Tietenkin soitetaan myös pitkiä ääniä. Tuomisalon mukaan tätä on hyvä tehdä aluksi ilman vibratoa, jotta äänen pohja saadaan kuntoon. Myöhemmin ääneen lisätään vibrato mukaan. Vibraton harjoittelemiseksi on olemassa omat menetelmänsä, kuten vibraton suhteuttaminen metronomin pulssiin. Näistä menetelmistä haastateltavat eivät kuitenkaan puhuneet erikseen. 
Malliksi soittaminen on tärkeä menetelmä opetuksessa. Keikkonen kertoo päässeensä hyviin tuloksiin tällä tavoin. Oppilas muodostaa kuvan äänestä kuulemansa perusteella ja pyrkii sitten matkimaan sitä. Keikkosen mielestä asioita ei pitäisi aluksi liikaa pyrkiä selittämään oppilaalle. Luotetaan siis oppilaan omaan kykyyn ratkaista äänenmuodostuksen ongelmia, kun ihannemalli on selkeä. Myöhemmin äänenmuodostuksesta voidaan sitten erottaa eri osa-alueita, joiden toimintaan voidaan keskittyä erikseen. Keikkonen pitää tärkeimpinä alueina hengityksen, kurkunpään asennon ja ansatsin kehittämistä. Hengitys on olennaista saada ajatuksellisesti riittävän alas. Kurkunpää pitää saada avonaiseksi ja ansatsi joustavaksi.

Opetuksessa voidaan malliksi soittamisen lisäksi käyttää apuna laulamista ja mielikuvia. Tärkeä ja paljon käytetty ääneen liittyvä mielikuva ovat jousisoittimet. Keikkonen kertoo myös toisinaan puhuvansa äänestä väreinä. Hän voi kuvailla oppilaalle esimerkiksi alempaa rekisteriä "ruskeana" ja ylempää "keltaisena". Artikulaation opettamiseen voidaan käyttää äänteiden matkimista: oikea kielen asento voi löytyä esimerkiksityy-äänteen avulla. Keikkosen mukaan tärkeintä on löytää oppilaan ja opettajan väliltä yhteinen kieli ja toimivat mielikuvat, ei niinkään se, selitetäänkö kaikki asiat juuri niin kuin niiden todellinen fysiologinen perusta on.

Selkeät menetelmät auttavat oppilaita hankkimaan selkeät taidot. Savijoki puoltaa Deffayet'lta oppimaansa tapaa, jossa kukin oppilas soittaa muiden oppilaiden edessä, ja kaikki kuuntelevat tarkkaavaisina kommentoimatta soittoa ääneen. Kaikki opiskeltava musiikki - asteikot, etydit ja kappaleet - oli siis Deffayet'n metodissa esitettävä julkisesti. Tämä motivoi oppilaat harjoittelemaan paljon. Opittavaa musiikkia oli kerralla paljon ja saattoi olla nöyryyttävää, jos ei osannut läksyjään. Vaikka Savijoki käyttää samaa metodia, hän on halunnut kuitenkin välttää oppilaiden julkista nöyryyttämistä. Menetelmän tuloksena kaikki diplomitason saksofonistit osaavat Savijoen mukaan teknisessä mielessä soittaa.

Opetuksen metodit ovat siis peräisin lähinnä ranskalaisen koulukunnan tärkeimmiltä opettajilta Daniel Deffayet'lta ja Marcel Muleltä. Ne eivät muutu kovin nopeasti, sillä ihanteet ovat melko samanlaiset kaikilla opettajilla. Nuoremmat tuntuvat seuraavan hanakammin myös uusia tuulia kansainvälisessä mittakaavassa. Myös nykymusiikin uudet ilmaisukeinot asettavat haasteita opetukselle, kun saksofonin ääniala kasvaa ja mukaan otetaan erilaisia efektien tuottamiseen tarvittavia tekniikoita kuten moniäänisesti soittaminen tai slap-kielitys. Opetuksen joustavuuden suhteen klassisessa saksofoninsoitossa näyttäisi olevan kahdenlaista lähestymistapaa. Savijoki korostaa tapaa, jossa kaikille opetetaan asiat samalla tavalla. Keikkonen kuitenkin toteaa, että oppilaat saattavat tarvita persoonallisen suunnitelman äänenlaadun kehittämiseksi. Hänen mukaansa oppilaiden äänten kvaliteettien välillä sallitaan pieniä eroja, vaikka äänen suhteen pyritäänkin tiettyihin yhteisiin ihanteisiin.

Haastatellut korostavat kriittistä asennetta saksofoninsoitonopetuksessa. Lyhyestä perinteestä, vähäisestä kilpailusta ja melko suppeasta ohjelmistosta johtuen 
saksofonin soitto ei Savijoen ja Tuomisalon mielestä ole aina ollut muiden orkesterisoittimien tasolla. On opittava elämään sen kanssa, että ei yksinkertaisesti ole olemassa esimerkiksi Brahmsin saksofonikvintettoa. Tavoitteena onkin ollut nostaa saksofoni samalle tasolle muiden klassiseen perinteeseen kuuluvien instrumenttien kanssa ja pitää se siellä. Tässä pyrkimyksessä äänenlaatu vibratoineen ja sävelpuhtauksineen on avainasia.

\section{Johtopäätökset}

Saksofoni on soinnillisesti hyvin rikas instrumentti. Soittimen ääntä on mahdollista muokata hyvin monenlaisten musiikinlajien ja musiikkityylien sekä musiikillisten tilanteiden vaatimuksiin.

Klassinen saksofoninsoitto ja jazzsaksofoninsoitto eroavat merkittävästi toisistaan äänenlaadun, soinnillisten ihanteiden, äänenmuodostuksen ja sen opetuksen osalta. Äänenlaadussa ero on toisinaan niin suuri, että esimerkiksiklassiseen saksofonityyliin perehtymätön kuulija saattaisi erehtyä luulemaan saksofonia kokonaan toiseksi instrumentiksi. Monet muusikot ovatkin itse asiassa sitä mieltä, että kyse on tavallaan eri instrumenteista. Tämä kanta on siinä mielessä perusteltu, että klassinen ja jazztyylinen saksofoninsoitto ovat kaksi eri perinnettä, joille kummallekin on kehittynyt oma estetiikkansa.

Äänenlaadullisia eroja kahden saksofonityylin välillä on vaikea kuvailla, koska myös yksittäisten saksofonistien äänenlaadun välillä on eroja. Kuitenkin tässä tutkimuksessa tarkasteltua ranskalaisperäisen klassisen saksofonityylin ääni-ihannetta voisi luonnehtia esimerkiksipuhtaaksi, hälyttömäksi ja säännölliseksi jazzmusiikin äänellisiin ihanteisiin verrattuna. Klassisen saksofonin soitonopettajien mukaan oleellista äänenlaadussa on ehdoton sävelpuhtaus, tasapainoinen perusääniaines ja hallittu ja tasainen vibrato. He luonnehtivat hyvää saksofonin äänenlaatua myös mm. "lämpimäksi", "pyöreäksi", "mehukkaaksi" ja "täyteläiseksi". Myös jazzsaksofonistien ihanteissa on usein havaittavissa pyrkimys tasapainoiseen ja hallittuun sointiin. Kuitenkin jazzsaksofonin äänessä sallitaan usein enemmän erilaisia suhinoita ja ikään kuin "ylimääräisiä" elementtejä kuten korostettuja artikulaatio-, hengitys-, ja puhallusääniä. Vibrato on usein vaihtelevampi. Äänen perussävy saattaa olla yläsävelkoostumuksen suhteen laajemman tai hajanaisemman kuuloinen.

Haastatellut jazzsaksofonipedagogit korostavat klassisia opettajia enemmän persoonallisen äänenlaadun merkitystä soittamisen kokonaisuuden kannalta. Vaikuttaakin siltä, että klassisessa musiikissa saksofonistien äänenlaadussa tietyn koulukunnan kuten ranskalaisen tyylin sisällä sallitaan vähemmän persoonallisia eroja kuin jazzmusiikissa. Ero kahden jazzsaksofonistin äänenlaadun välillä voi olla niin suuri, että vastaava ero klassisella puolella voisi synnyttää kokonaan uuden koulukunnan. Näin on käynytkin, 
sillä mm. Rascherin saksofonikoulukuntaa ja ranskalaista Marcel Mulen edustamaa tyyliä pidetään hyvin erillisinä saksofonistien keskuudessa. Esimerkiksi ajatus kamarikokoonpanosta, jossa soittaisi molempien suuntausten edustajia, lienee vieras.

Yksi syy siihen, että klassisessa musiikissa ei haluta saksofonistien äänenlaatujen eroavan toisistaan yhtä paljon kuin jazzmusiikissa, saattaa olla pyrkimys tasapainoiseen yhteissointiin saksofonien sekä saksofonien ja muiden orkesterisoittimien - erityisesti klarinettien ja huilujen kanssa kamari- ja sinfoniaorkesterissa. Saksofoninsoitonopettajat viittaavatkin usein jousisoitinten äänenkvaliteettiin saksofonin sointiihannettaan kuvatessaan. Toisaalta yhdenmukaisemmalle soinnille voisi toisinaan olla käyttöä myös jazzmusiikin piirissä, sillä ainakin big bandien saksofonisektioissa yhteisen soinnin löytäminen voi olla vaikeaa jos soittajien äänenlaadut poikkeavat huomattavasti toisistaan. Toinen syy klassisen musiikin saksofonin äänenlaadun erityispiirteille on soittotekninen: vireessä soittaminen, eri nyanssien hallittu tuottaminen ja $\mathrm{mm}$. laajat intervallit ja selkeän artikulaation vaatimus asettavat soittotekniikalle tiettyjä vaatimuksia. Esimerkiksi tiukkaa ansatsia voidaan selittää soittotekniikan käytännöllisyydellä. Kolmanneksi klassisen saksofoninsoiton ääni-ihanne on tietenkin osittain tulosta koko länsimaisen klassisen musiikin tradition käsityksistä ja arvoista.

Tärkeimmät erot saksofonin äänenmuodostuksesta klassisen saksofonin ja jazzsaksofoninsoiton väliltä löytyvät ansatsista, vibratosta ja artikulaatiosta. Klassisen saksofonistin ansatsi on usein huomattavasti tiukempi kuin jazzsaksofonistin. Ansatsi ei klassisen saksofonistin tekniikassa myötäile yhtä paljon kuin jazzsaksofoninsoitossa. Alahuuli on usein käännetty alahampaiden päälle, kun taas monet jazzsaksofonistit antavat alahuulen kontrolloida äänen väriä, virettä ja syttymistä eteen ja taakse päin rullaavalla hienovaraisella liikkeellä kääntämättä alahuulta sisäänpäin. Ansatsin erilaisuus vaikuttaa vibraton tekniikkaan. Jazzsaksofonisti saattaa muutella vibraton tuottamistapaa ja liikkeen voimakkuutta paljon enemmän kuin klassinen saksofonisti. Myös artikulaatiotavoissa on eroa. Jazzissa artikulaatiossa saatetaan käyttää joskus myös ilma-aluketta, kun taas klassisessa musiikissa artikulaatio tapahtuu säännönmukaisemmin kielittämällä. Jazzsaksofonisti saattaa käyttää myös enemmän ns. puolikieltä, jossa äänenvärähtely ei lakkaa kokonaan, saadakseen aikaan ns. ghostefektejä, joissa toiset äänet korostuvat toisten kustannuksella. Saksofonin äänestä puhuttaessa artikulaatio korostuu usein äänenmuodostuksen oleellisena osana nimenomaan jazzsaksofoninsoiton kohdalla. Kaikki klassiset saksofonistit eivät miellä artikulaatiota varsinaisen äänenmuodostuksen sisälle tai äänenlaadun merkittäväksi osatekijäksi. Jazzmuusikolle artikulaatiotavat voivat olla merkittävä keino esimerkiksi soittajan tunnistamisessa.

Myös jazzsaksofoninsoiton tekniikka on luotu niihin tilanteisiin sopivaksi, joihin soittaja jazzmusiikkia soittaessaan päätyy. Improvisaatio on olennainen osa jazzmusiikkia ja se ulottuu myös äänenmuodostuksen alueelle. Jotta jazzin estetiikka toteutuisi, pitää soittajan pystyä varioimaan saksofonin äänen sävyä, vibratoa ja 
artikulaatiota. On mielenkiintoista, että persoonallisen äänenlaadun lisäksi usein myös taito kuulostaa joltakin tietyltä soittajalta ja kyky muokata ääntä esimerkiksi sektiossa soittamiseen sopivaksi katsotaan saksofonistin ammattitaitoon kuuluvaksi.

Soinnilliset ihanteet ja äänenmuodostuksen erot näkyvät myös saksofoninsoitonopetuksessa. Äänenmuodostuksen tekniikkaa opetetaan tyylin perinteiden mukaan. Jazzopetuksessa rohkaistaan usein oppilasta enemmän "oman äänen löytämiseen", vaikkakin jotkut opettajat korostavat matkimismenetelmän merkitystä toisia enemmän. Tätä menetelmää käytettäessä ei päämääränä kuitenkaan ole mahdollisimman samankaltaisen äänen tuottaminen myöhemmässä kehitysvaiheessa, vaan ainoastaan tiettyjen tyylin perusperiaatteiden omaksuminen ja teknisten edellytysten kehittäminen. Klassisessa opetuksessa käytetään usein menetelmää, jossa opettaja soittaa oppilaalle malliksi, jotta oppilas sisäistäisi tietynlaisen sointi-ihanteen. Opetusmenetelmät tuntuvat vaihtelevan jazzopetuksessa hiukan enemmän oppilaan mukaan, mutta enemmän joustavuus riippuu opettajasta kuin opetettavasta tyylistä.

Klassisessa saksofoniopetuksessa käytetään opetusmateriaalina paljon etydikokoelmia ja tietenkin varsinaista esitettävää ohjelmistoa. Myös asteikot ja sointuarpeggiot ovat tärkeätä harjoitusmateriaalia. Nykymusiikin soittotekniikat tarjoavat klassisen saksofonin opetukselle uusia haasteita. Jazzsaksofonin opetus on musiikin improvisaatiota korostavasta luonteesta johtuen vähemmän progressiivisesti etenevää. Materiaalin käyttö vaihtelee enemmän eri opettajien välillä.

Klassinen saksofoninsoitonopetus vaikuttaa jazzopetukseen verrattuna hitaammin muuttuvalta ja homogeenisemmalta eri opettajien välillä. Tämä johtunee siitä, että klassisella opetuksella on selkeämmät yhteiset periaatteet, jotka Suomessa tulevat enimmäkseen yhdestä lähteestä: ranskalaisesta saksofoniperinteestä. Klassinen saksofoniopetus on varsinkin Suomessa nuorta, mutta jazzsaksofonin opetus etenkin oppilaitoksissa on vielä nuorempaa.

\section{Lähteet}

\section{KIRJALLISUUS}

Baines, Anthony (1991) Woodwind instruments and their history. New York: Dover Publications, Inc.

Berliner, Paul F. (1994) Thinking in jazz. The infinite art of improvisation. Chicago: The University of Chicago Press.

Delangle, Claude \& Michat, Jean-Denis (1998) "The contemporary saxophone. Saxophone today". The Cambridge companion to the saxophone. Ed. Richard Ingman. Transl. Peter Nichols. United Kindom: Cambridge University Press. S. 161-183.

Dryer-Beers, Thomas (1998) "Influential soloists". The Cambridge companion to the saxophone. Ed. Richard Ingham. United Kindom: Cambridge University Press. S. 37-50. 
Horch, Kyle (1998) "Saxophone technique. The mechanics of playing the saxophone". The Cambridge companion to the saxophone. Ed. Richard Ingham. United Kindom: Cambridge University Press. S. 75-87.

Hornbostel, Erich M. von \& Sachs, Curt (1974) "Soitinten luokitusjärjestelmä". Suomentanut Timo Leisiö. Musiikki 1-4/1974, s. 9-74.

Ingham, Richard (1998) "Jazz and the saxophone". The Cambridge companion to the saxophone. Ed. Richard Ingham. United Kindom: Cambridge University Press. S. 125152.

Liebman, David (1994) Developing a personal saxophone sound. Medfield, Massachusetts: Dorn Publications, Inc.

Liebman, David (1996) Self-portrait of a jazz-artist - musical thoughts and realities. Rottenburg N., Germany: Advance Music.

Luckey, Robert A. (1992) Saxophone altissimo. Lafayette, LA: Olympia music publishing.

Rascher, Sigurd M. (1977) Top tones for the saxophone - Four-octave range. New York: Carl Fischer, Inc.

Roach, David (1998) "Jazz and rock techniques. The mechanics of playing the saxophone". The Cambridge companion to the saxophone. Ed. Richard Ingham. United Kindom: Cambridge University Press. S. 88-93.

Teal, Larry (1963) The art of saxophone playing. Miami: Summy-Birchard, Inc.

Turner, Nick (1998) "The saxophone family: playing characteristics and doubling. The mechanics of playing the saxophone". The Cambridge companion to the saxophone. Ed. Richard Ingham. United Kindom: Cambridge University Press. S. 94-100.

\section{HAASTATTELUT}

Kaikissa haastatteluissa on haastattelijana ollut Matti-Juhani Orpana. Nauhat ovat tekijän hallussa.

Aaltonen, Juhani (2001) Vantaa 7.6.2001.

Heinilä, Kari (2001) Helsinki 23.8.2001.

Keikkonen, Juha (2001) Helsinki 25.9.2001.

Pylkkänen, Pekka (2001) Helsinki 2.2.2001.

Savijoki, Pekka (2001) Helsinki 27.6.2001.

Tuomisalo, Olli-Pekka (2001) Helsinki 23.1.2001. 